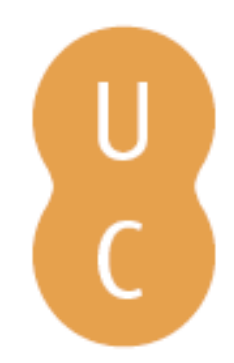

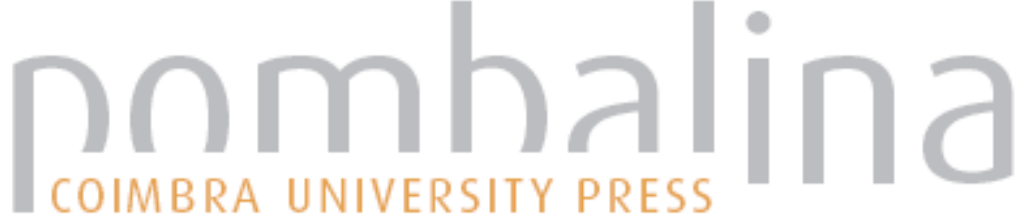

\section{Apollonius of Rhodes and the Universe of the Argonautica}

Autor(es): $\quad$ Fialho, Maria do Céu

Edições Afrontamento; CITCEM - Centro de Investigação

Publicado por: $\begin{aligned} & \text { Transdisciplinar «Cultura, Espaço e Memória»; Centro de Estudos } \\ & \text { Clássicos e Humanísticos; Alexandria University; Imprensa da }\end{aligned}$

Universidade de Coimbra

URL

persistente:

URI:http://hdl.handle.net/10316.2/36168

DOI:

DOI:http://dx.doi.org/10.14195/978-989-26-0966-9_10

Accessed : $\quad$ 26-Apr-2023 09:26:18

A navegação consulta e descarregamento dos títulos inseridos nas Bibliotecas Digitais UC Digitalis, UC Pombalina e UC Impactum, pressupõem a aceitação plena e sem reservas dos Termos e Condições de Uso destas Bibliotecas Digitais, disponíveis em https://digitalis.uc.pt/pt-pt/termos.

Conforme exposto nos referidos Termos e Condições de Uso, o descarregamento de títulos de acesso restrito requer uma licença válida de autorização devendo o utilizador aceder ao(s) documento(s) a partir de um endereço de IP da instituição detentora da supramencionada licença.

Ao utilizador é apenas permitido o descarregamento para uso pessoal, pelo que o emprego do(s) título(s) descarregado(s) para outro fim, designadamente comercial, carece de autorização do respetivo autor ou editor da obra.

Na medida em que todas as obras da UC Digitalis se encontram protegidas pelo Código do Direito de Autor e Direitos Conexos e demais legislação aplicável, toda a cópia, parcial ou total, deste documento, nos casos em que é legalmente admitida, deverá conter ou fazer-se acompanhar por este aviso. 


\title{
APOLLONIUS OF RHODES AND THE UNIVERSE OF THE ARGONAUTICA
}

\author{
MARIA DO CÉU FIALHO
}

University of Coimbra. Centro de Estudos Clássicos e Humanísticos (University of Coimbra).

\begin{abstract}
The Argonauts' saga belongs to an ancient repertory of mythical narratives set in the Eastern Mediterranean basin, about heroic journeys to a hostile unknown world in search of an invaluable object with unimaginable power. To obtain it, the hero and his journey companions must be brave enough to overcome several obstacles, which include human ensnarement, a wild indomitable nature and monstrous entities, almost personified entities. The narrative thus evolves around a kind of initiation journey that only exceptional men can successfully undertake. This type of narrative would come to inspire the western concept of journey, by land or sea, in quest of other objects with all sorts of powers. Apollonius would become the inspirational model for Roman poets such as Valerius Flaccus, Virgil and Ovid. We will briefly explore the contents of the Argonautica as the result of a new world vision of the Hellenized world that sprung in Alexandria under the inspiration of the Library.
\end{abstract}

In Theocritus's work The Idylls VII, known as Thalysiae, one of the participants in the contest ponders metapoetic issues: both contenders agree that one should discard aesthetic standards that support poems the size of high mountains hindering and preventing the flight of birds, something the Muses prize; followers of such standards are also to be repudiated ${ }^{1}$.

\footnotetext{
${ }^{1}$ Vv. 59-60 et passim.
} 
The focus of this critique of tastes might be the magnitude of epic poetry, by comparison with the elaborate, erudite and exotic natured encomium, in the shape of a hymn to the gods, like Callimachus's work, which questions traditions and is deeply influenced by ekphrasis ${ }^{2}$, or by comparison with the poetry rooted in the local traditions of a vastly hellenized world - such traditions embody a literary synthesis that reflects the biographical mobility and cultural formation of anyone who writes poetry and is inspired by the trials of love.

At the dawn of Alexandrine culture, Homeric epic, which informed the old Hellade, is not considered as the quintessential aesthetic model that inspires the epic poetry of new times $^{3}$. The precious and elaborate jewels of archaic poetry are preferred to Homer. There are scarce traces of Hellenistic epic composition corresponding to the origin and development of the great cultural centres. Also from the 4th century B.C., there is information, along with a few fragments, about an epic poem by Antimachus of Colophon, one of the first poetae docti $(R E)$, author of a Thebaid ${ }^{4}$. Apparently the action unfolds under the spell of erotic passion.

This shift in poetic taste, at the dawn of a new era, is corroborated by fragments of other narrative poems in elegiac metre, probably from the 3rd century B.C., by Hermesianax of Colophon or by Phanocles. However, as noted by P. M. Fraser ${ }^{5}$, these authors do not help us to contextualize the unique specificity of the Argonautica. The unique nature of this poem did not bring acceptance nor success as expected by the prestigious former head of the Library of Alexandria. In fact, Apollonius would become the inspirational model for Roman poets. Valerius Flaccus's version of the Argonauts' saga owes much to Apollonius but, prior to him, Vergil and Ovid were influenced by the poetic construction of Medea's outburst of passion, against her own will, and to Apollonius's construction of figures - such influence is attested by Dido's flare-up of passion in Aeneas's Aeneid and by Medeia the witch's semi-demiurgic profile, who fell in love with Jason, in Ovid's Metamorphoses ${ }^{6}$. And yet Apollonius's poem mirrors the ideology and expectations of new times and aesthetics; as I have demonstrated elsewhere, that new era and its aesthetic values contributed to the genesis of a new genre: the novel ${ }^{7}$.

\footnotetext{
${ }^{2}$ Callimachus's poetry is rich in descriptive leitmotive. To be noticed are those which concern female characters. They show how near poetry and sculpture were - what is testified, e.g., by the motive of the bath and of the female nude (Hymn to Athena).

${ }^{3}$ This is probably one of the reasons for the moderate success of Apollonius' epos. The Homeric Hymns, however, were highly appreciated as an inspirational source for Hellenistic poets - already for Callimachus' predecessors, also for Callimachus and for the following generations of poets: «In the Hellenistic age the composition of hymns to deities continued on a considerable scale, perhaps even increased», FRASER, 1972: 650.

${ }^{4}$ RE s. u. «Antimachos».

${ }^{5}$ Op. cit. 624-625.

${ }^{6} 7.74$ sqq.

${ }^{7}$ FIALHO, 2005: 33-47.
} 
The Argonauts' saga belongs to an ancient repertory of mythical narratives set in the Eastern Mediterranean basin, about heroic journeys to a hostile unknown world in search of an invaluable object with unimaginable power. To obtain it, the hero and his journey companions must be brave enough to overcome several obstacles, which include human ensnarement, a wild indomitable nature and monstrous entities, almost personified, entities. The narrative thus evolves around a kind of initiation journey that only exceptional men can successfully undertake, bringing back the long-sought invaluable object, often obtained with the help of divine entities. This type of narrative would come to inspire the western concept of journey, by land or sea, in quest of other objects with all sorts of powers. It is the author of the Odissey himself who establishes the relative chronology of the Argonauts' search for the Golden Fleece (12.69 sqq.), by having Circe warnig Ulysses about the perils of navigating near the Clashing Rocks (Symplegades), something accomplished only by «the Argo known to all» - and even so with Hera's aid.

Apollonius organized his poem into four chapters, the third one being the highlight. When Jason arrives in Colchis, he will not reveal his identity; Hera and Athena decide to help him, persuading Aphrodite to send Eros to Colchis. These parallel plans are striking: they portray deities playfully deciding the fate of human affections, of mortal men and women turned into objects of cruel entertainment. Is the depiction of the aristocratic Aphrodite, combing her long hair while she meets with the goddesses, to be taken seriously $^{8}$ ? It is worth noting, in this epic context, the motif of the female hair, sung in epigrams at the time, represented in the marble heads of statuary ${ }^{9}$. The cruel, troublesome prankish boy, as portrayed in ancient representations of erotes, strikes Medea. The symptoms of her uncontrollable passion for the foreigner, the attempted concealment and the stunning vision of Jason devastate the young witch, who tries (to no avail) to fight her feelings; her frailty is revealed when she hides or when she confides in her sister, during the night, in the intimacy of the palace. In his description of the signs of the princess's amatory pathos, Apollonius draws on archaic Greek poetry, on Sapho's famous poem on jealousy (frg. 31 LP), bowing to contemporary tastes (3. 962-965): «Her heart fell from out her bosom, and a dark mist came over her eyes, and a hot blush covered her cheeks. And she had no strength to lift her knees backwards or forwards...».

Such a suffering soul, somewhat resembling Nausicaa and a tragic Medea, bears the relief and material tension of figures distorted by physical pain typical of Hellenistic sculpture.

Medea leaves the palace at night and wanders the woods, a love-stricken sorceress searching in Hecate's secrets for magic that will enable Jason to overcome the super-human trials and snatch the Golden Fleece. Her passion has nothing to do the with the love magic

\footnotetext{
${ }^{8}$ BEYE, 1982: 8, «In both instances, the Callimachean and the Apollonian, the heroic detail has been domesticated».

${ }^{9}$ E.g. Callimachus' Berenice's hairs.
} 
that drives Simeta, in Theocritus's Idyll II, to perform nightly rituals, her slave and the moon as her confidantes, almost having an epiphany of Hecate. Nonetheless, the magic that Medea uses to ensure Jason's victory is obviously intended to gain Jason's affection. The reader cannot but be sensitive to Apollonius's delighted narrative of a night stirred by Eros and dominated by esoterism and the godess's revelation to the nocturnal young maiden.

In the first part of Book IV, Medea almost demands to go with Jason, a wavering hero, reminding him of their pacts and the bonds of plea, much alike Euripides's Medea ${ }^{10}$.

The core of Apollonius's epic poem is thus the erotic plot - the poem is dominated by deities that manipulate humans and by Medea, who, in spite of her frail esoteric nature, rises above the epic hero. Jason is a hero up to the moment when he hides with the Argonauts amid the reeds on the shores of Colchis. From thereon, the character expected to be the true protagonist emerges with a new dimension, framed by the loss of companions during his journey to Colchis: he is almost an anti-hero. The seer Idmon dies in what will become Heraklea, Typhis falls ill and dies too. Herakles loses his friend Hylas, who is mortally attracted by a nymph for whom he pines throughout the woods, like an idyllic unconsolable shepherd, and is left behind.

Death follows the Argonauts and Medea when they leave Colchis and also when they arrive in Lybia, where one more Argonaut, Mopsos, dies from a snake-bite. Death will lead them to Crete, where Medea's evil eye slays the giant Talos. These are not merely names left behind, bur rather human figures that suffer and arouse the pathos of those who lose them. This epic perspective is closer to an expanded universe where death is meaningless and no longer compensated for by the perpetuity of institutions; although the structures of home and family in the polis still exist, along with administrative and royal power, the meaning of their role has faded. Human powerlessness in the face of death and the harmful powers of the occult gradually lend consistency to the narrator's voice and identity (uncommon in ancient epic); for instance, when he tells us of the giant's slaughter by Medea's eye he remarks:

Father Zeus, surely great wonder rises in my mind, seeing that dire destruction meets us not from disease and wounds alone, but lo! even from afar, may be, it tortures us! So Talos, for all his frame of bronze, yielded the victory to the might of Medea the sorceress ${ }^{11}$.

As an author, Apollonius has the double ability to model his characters, with their contradictory behaviours and feelings; but he shows that same double mastery as an observer in the approach of the subject of his poem: as a scrutinizer of the human soul and an erudite scholar. Both abilities are balanced in a poem that is the product of its time and

\footnotetext{
${ }^{10} 4.66$ sqq.; 350 sqq. Cf. Euripides, Med. 475-498.

${ }^{11} 4.1673-1677$.
} 
that rises above the negative critiques it received - in fact, as noted by Brioso Sánchez ${ }^{12}$, such critiques have been disregarded for decades by modern research in Classical Studies.

In my opinion that balance stems from the predominant linear structure of the poem, narrated $a b$ ovo, from the moment they prepare for the journey and equip the ship, in Iolcos, to the moment of their return. The progression of the expedition enables Apollonius, the librarian, to explore the motif of prophecies, such as Phineas's and Mopsos's, and to embellish the itinerary, in the poem, with information on aitia of cults, like the Phrygians' Rhea-Cybele (1. 1130 sqq.), on the foundation of cities, toponomy - the author does so more often on the way to Colchis than on the return to Greece. The polygrapher Callimachus is the author of Aitia, with only a few fragments known to us, as of works that attest to his interest in Geography, about rivers, glossography of islands, cities and their foundation $^{13}$.

Some scholars have found it odd that Apollonius chooses a difficult route for the Argonauts to reach the shores of Greece, thus directing them to the Italic space where contemporary tradition placed Circe's home. The author interweaves several spaces, subtly bringing Alexandria into the geographical web of the story: this allows him to establish the interconnections between the new world and the mythical past.

It seems to me that the interest for the erotic phenomenology in the feminine soul is not the only reason why Apollonius raises Medea above Jason, for the Ptolemaic Dynasty also claimed to have its roots in Colchis. The adventure of the ship Argo takes the mythical heroes to Colchis, through dangers and initiation rituals, in order to bring back not only the Golden Fleece but Medea, who imposes her return on an insecure Jason. In his journey Jason encounters displaced figures, like Phineas, former king of Thrace, whom reveals the future of their journey ${ }^{14}$. Mopsos, the augur who descended from Apollo and Manto and was bred in Colophon, in Ionia, accompanies the expedition only to perish from a poisonous snake-bite on the shores of Libya - in Northern Africa, near Egypt - , to where the ship had been dragged. Their fate is shaped by mobility. Medea and the Argonauts come near of the future Alexandria and then continue towards West, where they find Circe, in a nearby space of barbarism, the axis of which has shifted West ${ }^{15}$. The outer reaches of this universe centred in Alexandria arouse the interest and imagination of geographers and adventurous explorers. There were several tales of journeys beyond the columns of Hercules. In the second half of the 4th century, Pytheas allegedly sailed to the Northern Seas; Alexander ventured into the unknown reaching India, inspiring the author of Story of Alexander. Greek imagination reaches northern borders, which are mentioned in Antonius Diogenes's The

\footnotetext{
12 This Hellenist points out how the epic text wins on expressivity by having been receptive to lyric resources, adequated to create an ambience of strong passion: BRIOSO SÁNCHEZ, 2003: 10 sqq.

${ }^{13}$ On the literary and research activity of Callimachus vide BRIOSO SÁNCHES, 1998: 795-802.

14 2. 316 sqq.

${ }^{15}$ ALVAR, 2008: 96-97.
} 
incredible wonders beyond Thule or in Antiphanes of Berges ${ }^{16}$ a story about a land that freezes in winter.

The journey of the Argonauts, with Medea and the Golden Fleece, represents the route from the borders of the Hellenized world to the mythical world, in the sense that to travel is to dominate the path and its inherent dangers, novelties and adventures, from North to West, in a circular route, along the borders of the world. Although the topography of the hydrographic basin of the Danube - the Greek Istros - was not known at the time, the river was believed to divide in two along its course: one of the channels flowed into the Adriatic Sea and the other into the Black Sea.

This might explain Apollonius's choice of itinerary for Argonautica. At the end of a periplos that reached Egypt ${ }^{17}$, Iolcos is the place to return to, bringing closer the sorceress of mythical times to the future Ptolemaic kingdom. To strengthen the links between the two eras, of myth and Alexandria, Apollonius resorts to the eternal strength of passion, the limitations of humankind, painfully experienced in death and mortality, the anxiety caused by unfathomable powers of obscure forces that convey failness and uncertainty to human existence. The author also resorts to the craftman's timeless repetitive daily work, the brute force of herds, the cattle, the hounds that run loose on the hills; the visual nature of these elements resemble a pictorial representation and are truly part of the wealth of erudition of this complex poem - its similes. Hunter highlights the degree of sophistication they can achieve, as part of a discursive strategy that convey the similes the mimetic qualities necessary to mirror the action as intended ${ }^{18}$. The reader is thus encouraged to confirm the correspondence between the comparitive dimension and the compared «ficional reality». The search for that key supplies the simile with polysemy and the epic discourse acquires a second sense. Such is illustrated in 2. 541-548, when Athena rushes to the aid of the Argonauts when they try to sail across Pontos against the Etesian winds:

And as when one roveth far from his native land, as we men often wander with enduring heart, nor is any land too distant but all ways are clear to his view, and he sees in mind his own home, and at once the way over sea and land seems slain, and swiftly thinking, now this way, now that, he strains with eager eyes; so swiftly the daughter of Zeus darted down and set her foot on the cheerless shore of Thynia.

The amplification of senses is a charming game for the reader, which would be difficult to follow for the listener of oral or publicly read poetry. The rich similes, descriptions and landscapes, the internal conflicts, the contrast in attitudes are for the competent reader

\footnotetext{
${ }^{16}$ GÓMEZ ESPELOSÍN, 2008: 66-78.

${ }^{17} 4.1228$ sqq. A strong north wind throws them away from their course, for nine nights and nine days - a magical number that underlines the quasi iniciatic dimension of this journey. Vide CLAUSS, 1993: cap. 7.

${ }^{18}$ HUNTER, 1993: 129-138.
} 
to evaluate. Besides, the librarian of the magnificent Library of Alexandria, wrote an epic with new undertones, clearly a product of its time; as such, it can only be properly appreciated and enjoyed if one bears in mind that it is a work intended to be read, as expected within a society where readers and books prevail for the next millenia. This sociological reality undoubtedly plays an important role in the creation of new genres and new forms of fictional writing. 